\title{
THE EFFECT OF PICTURE-CUED TASK TOWARDS STUDENTS' MOTIVATION IN LEARNING WRITING
}

\author{
${ }^{* 1}$ Warih Astuti, ${ }^{\# 2}$ Taufik Suadiyatno \\ ${ }^{* 1}$ English Student, FBMB, Universitas Pendidikan Mandalika, Indonesia \\ ${ }^{\# 2}$ English Lecturer, FBMB, Universitas Pendidikan Mandalika, Indonesia \\ Corresponding Author Email: taufiksuadiyatno@undikma.ac.id
}

\begin{abstract}
A B S T R A C T S
This study intended to find out the effect of Picture-Cued Task towards Students' Motivation in Learning Writing at SMPN 3 Lingsar in the academic year 2018/2019. The population of the second grade of SMPN 3 Lingsar was 120 students and the researchers took VIII-B class as an Experimental group and VIII-D as a Control group. The Experimental group was treated by Picture-Cued Task and the Control group was treated by Mind Mapping. The instruments that were used to collect the data were tests and questionnaires. The data was analyzed by using Quantitative research and the way researchers analyzed the data was by; scoring, percentile meanings, and impacts. The Quantitative Data showed that the students were able to arrange their grammar and vocabularies well when making short sentences through Picture-Cued Task. Those students were enthusiastically joined the class even though they were wondering what to do with pictures. In Quantitative Data, the researchers found; Mean $=26,07$, Median $=25$, Mode $=20$ and Standard Deviation $=$ 6,434 . The t-test score was 6,392 and the t-table was 1,67 in significance level 0,05 with the degree of freedom 54, therefore, the score of the ttest is higher than the t-table. Based on the data finding and discussion, it can be concluded that the use of Picture-Cued Task has a positive effect to motivate students in learning writing.
\end{abstract}

\author{
A R T I C L E I N F O \\ Article History: \\ Received: May, 2021
}

Revised: May, 2021

Published: June, 2021

Keywords:
Picture-Cued Task,
Motivation,
Writing,

Keywords:

Motivation,

Writing,

How to cite: Astuti, W., \& Suadiyatno, T. (2021). The Effect of Picture-Cued Task towards Students' Motivation in Learning Writing. Jo-ELT (Journal of English Language Teaching) Fakultas Pendidikan Bahasa \& Seni Prodi Pendidikan Bahasa Inggris IKIP, 8(1), 59-66. doi:https://doi.org/10.33394/joelt.v8i1.3798

\section{INTRODUCTION}

Writing is frequently useful as preparation for some other activity in particular when students write sentences as a preamble to discussion activities (Harmer, 2001: 255). This gives students time to think up ideas rather than having to come up with instant fluent opinions, something that many, especially at lower levels, find difficult and awkward.

Motivation is very useful for people and students who are studying writing. In order to make them feel free and know what to do, they need to have their motivation which is emphasized by the teachers. Motivation has an important role to have the learning process, especially in reading activities. According to Harmer (2001:51), motivation is a kind of interval drive, pushing someone to do things in order to achieve something. Furthermore, he suggests that motivation is a set of cognitive arousal which provokes a decision to act as a result of which there is sustained intel. Here, researchers focused on the motivation of the students. Motivation is a bit hard to be built but it is not impossible to do. With passion and 
honesty, researchers believe students would have their motivation. Richard and Rodger (2014: 34) proposed some important factors that affect motivation, which is; (a) Home and friends. The attitude of friends and family can have a big effect on children's motivation. If their parents encourage them to learn and their friends think that is cool to learn, they are more likely to be positive about learning. (b) Transfer ability. The students who can see how to transfer what they learn into other situations are more likely to have a higher motivation than those who do not seek out and recognize opportunities to use the new knowledge they learn. (c) Self-perception. To motivate students for the learning activity, it is important that they prepare themselves to be successful. (d) Absence of intrinsic reward. Intrinsic motivation is promoted by the sense of accomplishment obtained from struggling with something that is a bit difficult at first. Reward attends to encourage children to learn in order to get the rewards, not to achieve internal goals. It means that rewards may have an adverse effect on motivation. (e) Evaluation and threats. If children expect to be evaluated, feel threatened, or feel they are being watched and checked upon, it is likely that they will study for the sake of the evaluation, to avoid the punishment, or to satisfy the adults watching them, and will lose some inner motivation to learn for its own sake.

When the researchers conducted a pre-observation at SMPN 3 Lingsar in Academic Year 2018/2019, they found some problems, such as students' lack in their writing skill, so they could not write what they wanted to deliver ideas in good and correct vocabulary and grammar. Because of these things, the students did not have the motivation to learn to write. They felt low and sometimes being pressured of doing something they were asked. Students usually were confused about how to write and what to write, and then they finally gave up without doing anything. So to solve that serious problem, the researchers decided to help the students to do writing in a very simple way. Honestly, the method was a common thing that has been used by many motivators or teachers. The method would help the students to find out their lesson in a fun way; it seems like a cute game where they have to think about what to write without being annoyed or angry. Students' mental is important not to be broken up. Based on the problems above, the researchers were interested to conduct the study entitled "The Effect of Picture-Cued Task towards Students' Motivation in Learning Writing."

Spratt, Pulverness, and Williams (2005: 26) state that writing and speaking belong to productive skills. They say that speaking and writing produce language rather than receive it. It means that in writing, the output will be needed as an indicator that students have learned and understood the skills. It is clear that the output of writing skills can be written stories, letters, or other text types.

A Picture-Cued Task is one type of cognitive awareness-raising task (Skehan, 1998) in which learners' attention is directed toward silent features of one or a series of pictorial sketches, cartoons, or photos rendering a more concrete aspect of the meaning of a linguistic expression. Procedures of Picture-Cued Task teaching: a) Imitative writing; a task in (hand) writing letters, words, and punctuations. Here, the students will be given tasks by the teacher that contains some familiar pictures and the pictures are not ambiguous in identified. And then, the students will be asked to write the word(s) that the picture represents. b) Spelling task and detecting phoneme-grapheme correspondence; here, the students will be given pictures with focusing objects on familiar words that may be unpredictable spelling. This format presents some challenging words or words pair. c) Intensive (controlled) Writing; Picture-Cued Task is used in English classrooms around the world. The advantages of using Picture-Cued are; separate reading and writing connection and offering nonverbal means to stimulate written responses. d) Short sentences; the teacher gave the students a picture. Then, they will write the descriptions of the picture briefly. e) Picture description; to be more complex, pictures will be shown to the students. Students will write the description they find with a preposition such as: on, over, under, next to, and around. f) Picture Sequence 
Description; a sequence of three to six or more pictures depicting a storyline can provide a suitable stimulus for written production. Students cannot understand clearly the pictures if they are prepared ambiguous pictures, so they need simple pictures to be described with their words. Meanwhile, the time sequence in the following task is intended to give researchers some cues (Brown, 2004: 227-228).

\section{RESEARCH METHOD}

This current research used the quantitative method. This method emphasizes objective measurements and the statistical, mathematical, or numerical analysis data collected through tests and questionnaires. The type of quantitative method being applied was quasiexperimental research.

\section{Research Design}

In this research, the researchers used a quasi-experimental with non-equivalent control group design. This design is similar to the pre-test/post-test control group design. The sample of this research was determined by cluster random sampling technique. The researchers divided the sample into two groups of the sample using lottery technique. Those two groups were treated differently. The first group as an experimental group was treated by using Picture-Cued Task. Meanwhile, the second group, a control group was treated by Mind Mapping. Before giving the treatment, the researchers gave the pre-test to the students to find out the real ability of the students. Then, the researchers gave a post-test after treatment. The design of this research was described in table 1.

Table 1

Scheme of the Research

\begin{tabular}{|l|c|c|c|}
\hline \multicolumn{1}{|c|}{ Group } & Pre-Test & Treatment & Post-Test \\
\hline Experimental Group & $\mathrm{O}^{1}$ & $\begin{array}{c}\text { Picture-Cued Task } \\
(\mathrm{X})\end{array}$ & $\mathrm{O}^{2}$ \\
\hline Control Group & $\mathrm{O}^{3}$ & $\begin{array}{c}\text { Mind Mapping } \\
(-\mathrm{X})\end{array}$ & $\mathrm{O}^{4}$ \\
\hline
\end{tabular}

Sugiono, (2017)

Note:

$\mathrm{O}^{1}=\quad$ Experimental group

$\mathrm{O}^{2}=$ Control group

$\mathrm{O}^{3}=\quad$ Pre-test value for the experimental group

$\mathrm{O}^{4}=\quad$ Post-test value for the control group

$\mathrm{X}=$ Picture-Cued Task

$-\mathrm{X}=\quad$ Mind Mapping

\section{Population and Sample}

The population is a generalization region consisting of objects subjects that have certain qualities and characteristics applied to researchers to be studied and then drawn conclusions (Sugiyono, 2017: 61). The population, in this case, consisted of 120 students of the eighth grade at SMPN 3 Lingsar. The population in this research was all of the students in the eighth grade of SMPN 3 Lingsar that consisted of four classes, those were VIII A, VIII B, VIII C, and VIII D.

The sample is a part of the amount and characteristics (Sugiyono, 2017: 62). The researchers took two classes as samples using the cluster random sampling technique. Those classes were divided into two different groups; experimental and control groups. Then, the researchers took the VIII B class as the experimental group and the VIII D as the Control group. They were selected by using the lottery technique. The Experimental Group consisted 
of 28 students who were treated by using Picture-Cued Task. Different than this, the Control Group consisted of 28 students who were treated by using Mind Mapping.

\section{Instruments}

In collecting the data, the researchers used two types of instruments, they are writing tests and questionnaires. The writing test was divided into two; pre-test and post-test. The pre-test was given before treatment and the post-test was given after treatment. Meanwhile, the questionnaire consisted of 20 questions related to motivation in learning writing through Picture-Cued Task. Every question has a value ranging from 1-5 points. Those were $5=$ Strongly Agree, 4 = Agree, 3 = Undecided, 2 = Disagree and $1=$ Strongly Disagree (Gay, Mills \& Airasian, 2012)

\section{Data Analysis}

In the present study, the researchers used descriptive statistics and inferential statistics to calculate all of the data with SPSS 19 for software. Descriptive Statistic consists of mean, mode, and median. Inferential statistics is analysis derived from sample data that are used to make inferences about the population from which the sample is taken. In this research, the researchers used a t-test to compute the data which is the interval, and derived from two samples. Researchers compared the result of the t-test to the t-table. If the result of t-test $>\mathrm{t}$ table, the alternative hypothesis would be accepted, but if the result of t-test < t-table then the null hypothesis would be rejected.

\section{RESEARCH FINDINGS AND DISCUSSION Research Findings}

This research was conducted in November 2019 in SMPN 3 Lingsar. The researchers have done the research by eight meetings for each class in three weeks. The sample was divided into two groups; Experimental and Control groups. The total population was 120 students. Random Sampling Technique was used in this research where there were 56 students as the total sample and consisted of two groups, were VIII-B as the Experimental Group (28 students) and VIII-D as the Control Group (28 students).

Table 2

Descriptive Analysis Pre-test of the Experimental Group

\begin{tabular}{|l|r|}
\hline N $\quad$ Valid & 28 \\
& Missing \\
Mean & 0 \\
Median & 26.07 \\
Mode & 25.00 \\
Std. Deviation & 20 \\
Range & 6.434 \\
Minimum & 20 \\
Maximum & 20 \\
Sum & 40 \\
\hline
\end{tabular}

Researchers used SPSS 19 for software to find out the mean, median, mode, and standard deviation of the data. In table 2 shows the mean score was 26.07 , the median score was 25 , the mode score was 20 , and the standard deviation was 6.434 . here the frequency result of the distribution pre-test is shown in figure 1. 


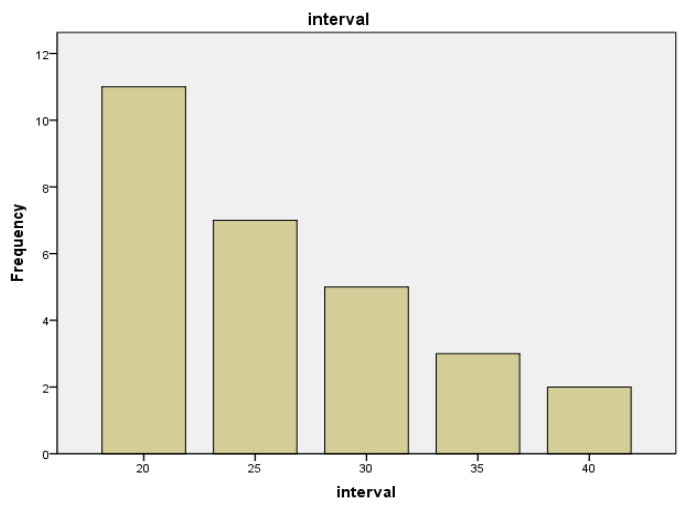

Figure 1. Interval of Pre-test of the Experimental Group

Figure 1 shows the data from the pre-test of the writing test. Data presented as the picture, then the data presented as a graphic. The result can be seen that the score at pre-test. 11 students got 20 scores, 7 students got 25 scores, 5 students got 30 scores, 3 students got 35 scores, and 2 students got 40 scores.

Table 3

Descriptive Analysis Post-test of the Experimental Group

\begin{tabular}{|l|r|}
\hline N $\quad$ Valid & 28 \\
& Missing \\
Mean & 0 \\
Median & 62.68 \\
Mode & 60.00 \\
Std. Deviation & 60 \\
Range & 6.452 \\
Minimum & 25 \\
Maximum & 50 \\
Sum & 75 \\
\hline
\end{tabular}

Researchers used SPSS 19 for software to find out the mean, median, mode, and standard deviation of the data. In table 3 shows the mean score was 62.68 , the median score was 60 , the mode score was 60 , and the standard deviation was 6.452 . 


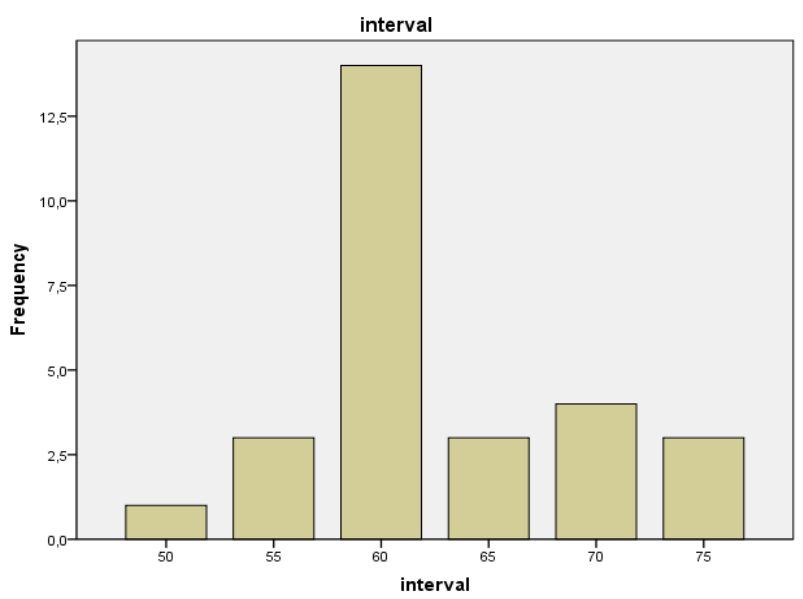

Figure 2. Interval of Post-test of the Experimental Group

Figure 2 shows the data from the post-test writing test. Data presented as the picture, then the data presented as a graphic. The result can be seen that the score in post-test. 1 student got 50 scores, 3 students got 55 scores, 14 students got 60 scores, 3 students got 65 scores, 4 students got 70 scores, and 3 students got 75 scores.

Table 4

Descriptive Analysis Pre-test of the Control Group

\begin{tabular}{|l|r|}
\hline N $\quad$ Valid & 28 \\
& Missing \\
Mean & 0 \\
Median & 18.04 \\
Mode & 15.00 \\
Std. Deviation & 15 \\
Range & 7.371 \\
Minimum & 25 \\
Maximum & 10 \\
Sum & 35 \\
\hline
\end{tabular}

Researchers used SPSS 19 for software to find out the mean, median, mode, and standard deviation of the data. In table 4 shows the mean score was 18.04, the median score was 15 , the mode score was 15 , and the standard deviation was 7.371 .

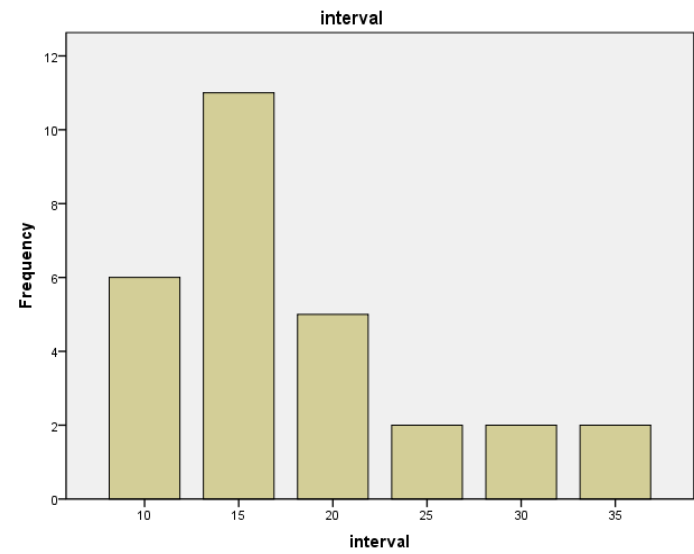

Figure 3. Interval of Pre-test of the Control Group 
Figure 3 shows the data from the pre-test of writing test. The data presented as a picture, then the data presented as a graphic. the result can be seen that the score in the pretest. 6 students got 10 scores, 11 students got 15 scores, 5 students got 20 scores, 2 students got 25 scores, 2 students got 30 scores, and 2 students got 35 scores.

Table 5

Post-test Descriptive Analysis of the Control Group

\begin{tabular}{|l|r|}
\hline \multicolumn{1}{|c|}{ Valid } & 28 \\
Mean & Missing \\
Median & 0 \\
Mode & 50.00 \\
Std. Deviation & 50.00 \\
Range & 55 \\
Minimum & 8.278 \\
Maximum & 40 \\
Sum & 20 \\
\hline
\end{tabular}

Researchers used SPSS 19 for software to find out the mean, median, mode, and standard deviation of the data. In table 5 shows the mean score was 50, the median score was 50, the mode score was 50, and the standard deviation was 8.278.

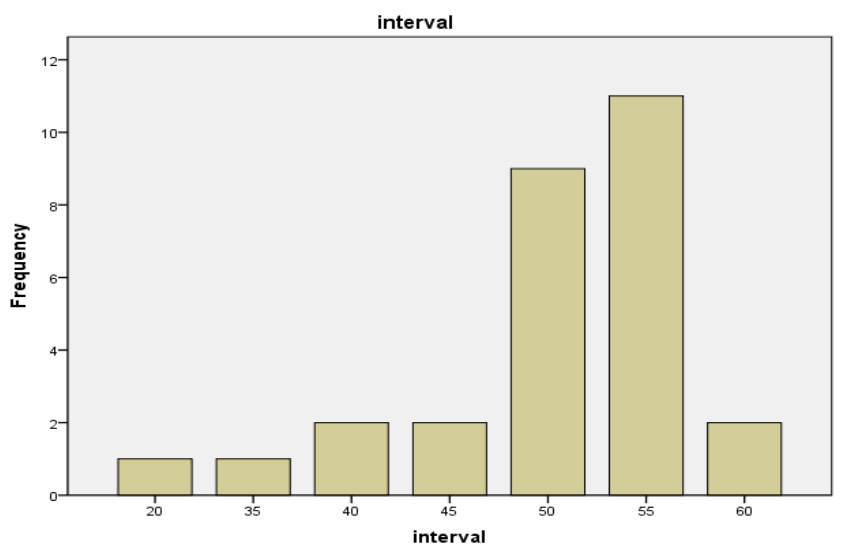

Figure 4. Interval of Post-test of the Control Group

Figure 4 shows the data from the post-test writing test. data presented as the picture, then it was presented as a graphic. the result can be seen that the score in post-test. 1 student got 20 scores, 1 student got 35 scores, 2 students got 40 scores, 2 students got 45 scores, 9 students got 50 scores, 11 students got 55 scores, and 2 students got 60 scores.

\section{Discussion}

The current research aimed to find out the effect of Picture-Cued Task towards Students' Motivation in Learning Writing. During the teaching and learning process, the students enjoyed the lesson that had been delivered using Picture-Cued Task. In applying this method, the researchers applied the procedures proposed by Skehan (1998). Those procedures are; a) Imitative writing, b) Spelling task and detecting phoneme-grapheme correspondence, c) Intensive (Controlled) Writing, d) Short Sentences, e) Picture Description, f) Picture Sequence Description.

The applying of Skehan (1998) theory was effective. It was proved by the result of testing hypothesis in t-test formula which showed that t-test value was 6,392 and t-table was 
1,67 in significance level 0,05 with the degree of freedom 54. It means that the score of the ttest is higher than the t-table $(6,392>1,67)$, it can be concluded that the Alternative Hypothesis (Ha) that is stated, "there is a positive effect of using Picture-Cued Task towards students' motivation in learning writing" was accepted.

Picture-Cued Task was effective and had a good reason to be used as one of the appropriate methods in learning writing skills. Basically, children love to play and see something colorful which can entertain their brain. Pictures stimulated the student's minds and formed their imagination about what they saw. In this case, Picture-Cued Task is a method that can be playful for students to encourage their motivation in learning writing skills. Thus, it is in line with what Harmer (2001:51) mentioned in his theory about motivation, in which motivation is a kind of interval drive, pushing someone to do things in order to achieve something. So, once students are motivated, they will feel easier to achieve their goal in learning writing, this fact is shown by the sample of the current research. They were able to arrange their good grammar and vocabularies when making good short sentences through Picture-Cued Task.

\section{CONCLUSION}

Based on the data analysis and the discussion in previous chapters, the researchers concluded that the Picture-Cued Task has a positive effect and it is efficient towards students' motivation in learning writing.

\section{REFERENCES}

Brown, H. D. (2004). Language Assessment: Principle and Classroom Practices. New York: Pearson Education.

Gay, L. R., Mills, G. E., \& Airasian, P. W. (2012). Educational Research: Competencies for Analysis and Application (10th Ed.). Pearson, Upper Saddle River.

Harmer, J. (2001). The Practice of English Language Teaching (3rd Ed.). Essex, England. Longman.

Richard, J. C., \& Rodgers, T. S. (2014). Approaches and methods in language teaching. Cambridge: Cambridge of University Press.

Skehan, P. (1998). A Cognitive Approach to Language Learning. Oxford: Oxford University Press.

Spratt, M. P. A., \& Williams, M. (2005). The Teaching Knowledge Text Course. Cambridge: Cambridge of University Press.

Sugiyono. (2017). Metode Penelitian Kuantitatif, Kualitatif, dan R\&D. Bandung: Alfabeta, $\mathrm{CV}$. 